\title{
A Probe into Impediments of Benefit Gain in Investment Contracts of Oil and Gas Industries
}

\author{
Nader Mardani ${ }^{1} \&$ Mohammad Mehdi Hooshmand ${ }^{1}$ \\ ${ }^{1}$ School of Law and Political Sciences, Shiraz University, Shiraz, Iran \\ Correspondence: Mohammad Mehdi Hooshmand, MA in International law, School of Law and Political Sciences, \\ Shiraz University, Shiraz, Iran. E-mail: M.Mehdi.Hooshmand@gmail.com
}

$\begin{array}{lc}\text { Received: March 21, } 2016 & \text { Accepted: May 23, } 2016 \quad \text { Online Published: June 29, } 2016 \\ \text { doi:10.5539/jpl.v9n5p31 } & \text { URL: http://dx.doi.org/10.5539/jpl.v9n5p31 }\end{array}$

\begin{abstract}
Generally, oil contracts comprise of a set of benefits in their own specific settings. Different technical, sometimes fundamental, factors may lead to imbalance in benefiting from the contract; this is considered as injustice in international relations and a violation to purpose of law. Therefore, seeking strategies to deploy justice in this field and offering strategies to find such strategies is of crucial importance. The present study is aimed at investigating impediments and factors that cause imbalance in equal gains of both parties in these contracts. Identification of these factors and the existing conditions significantly help realization of justice within a framework of rules and regulations. After carrying out deep analyses of oil contract and evaluation of the results, factors influencing this were identified; some of this factors such as contract parties and selection of the type of contract and currency system are related to the parties' will sand some others are related to conditions such as risks of economic policy making and of economic structures, while there is another case of gas and oil price fluctuations which is separate from the existing conditions or parties' wills. Therefore, it is of great importance to take these issues into account and to make attempts to follow them toward gaining benefit from oil contracts for oil companies, particularly those in countries where oil is the aim source of income.
\end{abstract}

Keywords: oil and gas contracts, oil and gas law, currency system, economic risk, oil and gas price fluctuations

\section{Introduction}

Advent of oil as a valuable commodity imposed great changes on the frameworks and fundamentals of economic relations. Following this, states' attitudes toward each other changed and their relations adopted new identities after the formation the first oil wells and technology development in gas fields. Need to this energy and oil caused extension of trade and new diplomatic relations of international law system. What adds to the importance of this notion is measures taken by followers in the fields ranging from states or international organizations to multi-national companies. What is noteworthy is prevalence of oil and gas resources in developing countries when technologies for their exploitation, discovering, refining, marketing, etc. are at the hands of states of developed countries; and this lack of congruence has made these states close together. This is because it is often claimed that developing countries lack enough investment, appropriate technical knowledge and fair managerial capacity to implement large-scale oil projects and this made the existence of oil companies more necessary. Hence, the controversy in adjustment of rules that are paramount in these relations is significant in law and is often disciplined in form of oil contracts with parties' intentions. However, the ultimate goal of laws, i.e. justice, requires that attempt be made to follow justice disregard of following rules so that proportionate benefit gains occur. In this respect, it is necessary to impediments of benefit gain in oil contracts be investigated as follows: contract parties, selection of contract type, risks of economic policy-making, economic structure risks, currency system, oil and gas price fluctuations in the global market.

\section{Statement of the Problem}

Investment and implementation of oil operations by the private sector, including both internal and external operations, take place through oil contract. ${ }^{1}$ Oil contracts are diverse in gas and oil legal system and are identified in different classifications and sectors with their own specific frameworks. Generally speaking, these contracts can be divided into the following types:

\footnotetext{
${ }^{1}$ - Shiravi, Abdolhossein, oil and gas law(in persian), Tehran: Mizan, 2014. P.353
} 
- Main upper-hand contract including concession agreements (e.g. licenses and rents)

- Joint venture agreements

- production sharing contracts(including revenue sharing contract)

- $\quad$ service contracts(including buyback contracts)

- Joint bidding agreement

- Joint operating agreement

- unitization agreements

- upper-hand financial provision agreements

- upper-hand secondary agreements

Downstream contracts including unit activity such as consulting services contracts, goods purchase and equipment order contracts, and contracting

Downstream contracts include diverse activities, such as:

- Engineering and goods provision contracts

- Engineering and building contracts

- Goods provision and building contracts

- Engineering, goods provision and building/ designing and building contracts

- Engineering, goods provision and building management contracts

- Engineering, goods provision and building, and financial support contracts

- Building, exploitation and assignment contracts

- Buy back contracts

Oil and gas trade contract include:

- Petroleum buying and selling contracts

- Gas buying and selling contracts

- Oil and gas swap contracts

- Offsets Contracts (balanced)

- Production Sharing Contracts (PSC)

\section{Analysis of Impediments}

\subsection{Contract Parties}

Contract parties are the most important factors that influence benefit gain in a contract. Also, the negotiating parties' capability to bargain is in direct relationship with their states or the states they negotiate on behalf of. This can have effects on benefit gains both before and after making the contract. Before assigning the contract, power of bargaining and imposition of commitment on one party can precede benefits for the other party. In other terms, the more powerful one party and the more politically influential it is in international arena, the easier it can impose commitments and have influence on the other party and, in this way, gain more benefits in the contract.

Regarding mutual influence in gaining benefit in the contract after entering into the contract, it can be expressed that the party with more political power is able to leave the oil contract half -way; for example, when French TOTAL Company left South Pars Projects unfinished in ASSALUYEH, Iran. So, the more powerful party can forget its commitments more easily. Moreover, in certain situations, very big oil companies can violate their some commitments; for instance, when a less politically powerful is sanctioned, companies can easily ignore implementation of some technologies and, instead, make use of older technologies in the project while it could have better efficiency, quality and speed if updated technology was used. As a result, contract parties, their political power, nationality, etc. can be effective in gaining benefit during making an investment contract in oil industry.

\subsection{Contract Selection}

No oil- or gas-related related contract is, in essence, good or bad. Type of a contract is, in fact, a framework for 
sharing benefits emerging from cooperation. In this sense, the notion of which type of contract could provide the parties' needs under what conditions is dependent on many factors. Oil companies and host countries gain interest in different contracts according to conditions. However, this tendency does not merely mean that their choice is the best or the one which guarantee their benefits. Selection of the contract type must be done according to different factors including internal political conditions, external political conditions, country's geopolitical status in the country, economic status of the country, country's economic status in an international arena, international procedures, status of global market, etc. The mentioned factors all affect selection of the type of contract. In harsh economic situations which might be the result of economic sanctions, the choice of buyback contract is a fair selection. However, only one choice must not be focused and attention needs to be paid to other factors, too. Furthermore, regarding underground oil and gas storage project, the choice of offset contract is fair if the aim is offering instruction on this technology; other conditions have been assumed stable. For instance, in oil or gas transference contacts, choices such as swap contract and negotiation with contract parties can be the most appropriate ones.

\subsection{Economic Policy Risk}

Economic policy risk is a reflection of the quality and stability of economic policies which is placed in a frame comprising of 27 different factors. These factors can be evaluated on the basis of five classes, namely financial, monetary, currency, trade and economic policies. Monetary policies decide on factors influencing inflation rate in the country. In fact, the lower the inflation rate in the host country, the less the decrease in property values and the lower net profit in investments and contracts. Consequently, risk in contracts is reduced and, as a result, direct foreign investment is increased.

Financial policies indicate state's budget deficit and tax incomes. The less the budget deficit and tax incomes the more powerful the financial policies. In case of budget deficit and its provision through taking out loans from the central bank, inflation would raise in the host country. This can have a negative effect on direct foreign investment. Also, double taxation on income in investing companies can have the same negative effects. It is obvious that the investor is not willing to pay taxes in two countries. Moreover, high amount of double taxation and profit obtained from production and servicing activities lead to decrease in their incomes after deduction of tax; with decrease of output, entry of direct foreign investment in the country would decrease, too.

Set of exchange policies is an indicator of the currency system status. If exchange rate remains stable, more trust would exist within the country's economic status and consequently decision-making would be facilitated for foreign investing companies. Moreover, existence of a multi-rate currency system would lead to investors' attempts to receive cheap currency or rent instead of enhancing the level of efficiency and exploitation, imposing negative effects on foreign investment.

Trade policies represent the amount of freedom within foreign trade. The more the customs exemptions for mediating institutes the foreign investors need, the more the foreign direct investment entering the country.

Economic balancing policies include formal and available information, setting direction of the government and society toward foreign investments and limitations on investment transference. The more clear and accessible the information, the more trust foreign investors would gain in their evaluations, which facilitate foreign investment in the country. In addition, people's attitudes and rules and obligations of investment can play a significant role in attracting foreign investment.

\subsection{Economic Structure Risk}

Economic structure risks are aimed at measuring the capability of paying back national debts to foreigners. These can be categorized into five conditions including economic growth, stable trade balance, financial structure and debts status.

Obviously, from an economic point of view, global status has a direct and undeniable effect on benefits gained from contract (oil contracts in particular). An example for this could be America's economic crisis in 2008 which colored the globe and removed the framework of many contract benefits.

Economic growth is comprised of many factors such as infrastructural equipment - expanded economic infrastructures such as roads, ports, communication systems, etc. are among the very influential factors in attracting contracts for high-benefit macro-investments- or specialized work labor and human resource development. When more complexity is observed in goods and service production in the world, specialized work labor is not a superiority anymore. Hence, those countries with trained work labor would be more successful in attracting direct foreign investment. An additional factor might be wide information network; this can provide foreign investors with updated information about work labor, privileges, etc. to make more motivated to directly 
invest in the country.

But, stable trade balance means stability of the foreign system and the more stable the foreign trade system the more trustful the foreign investors. Therefore, stable trade balance is in direct relationship with benefit gain in foreign, or even internal, oil and gas contracts.

Financial provision structure implies the more powerful the bank system in a country and the easier facilities it offers to the customers with no corruption or bureaucracy, the better the situation for foreign investment.

Foreign debts status; with decrease of foreign debts in a country, the possibility of financial provision through import of investment to the country can increase. Undoubtedly, this can have positive effects on benefit gain in contracts of gas and oil industry.

\section{Type of Currency System}

Currency rate system is generally classified into two groups, each with exclusive monetary and financial policies: Fixed Exchange Rate System and Floating Exchange Rate System. Selection of an appropriate currency system has always been one of economic policy makers' concerns in every country. In this respect, many theorists have made attempts to make issue of currency system issue clear to policy makers Generally speaking; three theories have been proposed for the selection of an optimal currency system in economic literacy. ${ }^{2}$ These theories discuss selection of an appropriate currency system from economic, political and financial dimensions. These theories include:

\subsection{Optimum Currency Area}

This theory was introduced by Mundell ${ }^{3}$ and McKinnon ${ }^{4}$ in 1960s. According to this theory, balance of advantages and disadvantages of both fixed and floating currency systems changes in accordance with characteristics and extension of economic merging. In other words, the more the merging for countries, the more the advantages of floating currency system than those of the fixed currency system and vice versa. Within the framework of this theory, selection of a currency system for a country must be done in compliance with structural features and economic criteria of those countries which remain quite stable in time. Based on this theory, mobility of work labor, openness of economy and diversity of products are decisive factors when selecting the currency system for countries.

\subsection{The Political Economy Theory}

Since the emergence of temporal disagreement and its extension, selection of a currency system for countries based on the political economy theory attracted attention. According to this theory, policy-makers' reliability and political factors have decisive effects on selection of currency system in countries.

\subsection{The Currency Crisis (Capital Openness)}

Currency crisis have demonstrated that those currency systems that are placed somewhere between the fixed and floating currency systems are more exposed to speculation. In this sense, when selecting their currency systems countries ultimately move toward marginal solutions. On the basis of this theory, countries need to either admit flexibility of the currency system or accept institutional necessities of fixed currency rates.

Economic and political sciences note that political parties have specific methods of policy making which are in line with their ideologies. ${ }^{5}$ States might either behave according to their ideologies or make attempts transform a piece of their ideologies to policy making. In this vein, political parties tend to link main effects of their policies to different purposes and motives. In other words, they are willing to present justifications, except from their purpose, for their own policies. Hibbs's (1977) influential investigation is the first document which shows that left-party states prefer low unemployment rate while tolerate high inflation rate in order to reach low unemployment rate. On the contrary, right-party states prefer lower inflation rates even if this ends in rise of unemployment rate. Within this framework, left-party states oppose unemployment while they oppose inflation less; the opposite stands true for right-party states. One main effect of state policies in economy roots in lack of harmony between right and left parties. ${ }^{6}$ Right-party states tend to preserve possession rights while left-party

2 - Mohamed Daly Sfia (2010) “The choice of exchange rate regimes in the MENA countries: a probit analysis", Int Econ Econ Policy (2011) 8:275-305.

3 - Mundell, R.A.(1969). “Toward a Better International Monetary System”. Journal of Money Credit and Banking, vol.3,PP625-648.

4 - McKinnon, R., (1963). “Optimum currency areas”. American Economic Review 53, 717-725.

5 - Hibbs, D., (1977). "Political parties and macroeconomic policies". The American Political Science Review 71, 1467-1487.

${ }^{6}$ - Potrafke, N., (2010). "Does government ideology influence deregulation of product markets? Empirical evidence from OECD countries". Public Choice 143, 135-155. 
states tend to interrupt economy. ${ }^{7}$ For instance, Bortolotti et al. ${ }^{8}$ and Potrafke ${ }^{9}$ state that right-party states have a tendency to privatization and de-regularization, approach enhancement and reformations in the market. Benoit and Laver ${ }^{10}$ demonstrated that right-party members focus their policy-making activities on de-regularization more than members of the left-party do. More obviously, market-entered and right-party people preach economic freedom and support minimum interruption in economy. Basically, with regard to their countries' economic structures, states need to select the appropriate currency system according. Although currency system is one of the most influential factors in countries' development, particularly in oil-production countries, economic structure is the least significant factor in selection of currency system.

\subsection{Factors Determining the Currency System}

State's Ideology: it has been reiterated in the literature that right-party and left-party states have different tendencies toward production, employment and price stability. Right-party states prefer low inflation rate while left-party states prefer low unemployment rate. ${ }^{11}$ In such condition, right-party choose fixed currency system so as to maintain a stable monetary policy, which finally results in low inflation. Moreover, states that prefer low inflation might consider the currency system fixed for aims of removing monetary policies. ${ }^{12}$ Therefore, assuming that right-party states tend to low inflation rate, they can reach fixed prices through adopting fixed currency system and stable monetary policies. On the contrary, the most salient advantage of a floating currency system is that it allows states implement independent monetary policies. ${ }^{13}$ Monetary policies can have great effects on employment and income rates because they catalyze capital flow. Nevertheless, lowering down the real currency rate concludes trade surplus. ${ }^{14}$ Floating currency system permits states improve competition atmosphere in the tradable sector by manipulating the formal currency rate.

Political institutes' status: status of internal political institutes can have significant impacts on adoption of the country's currency system. ${ }^{15}$ Democratic institutes facilitate the free flow of information and reduce the necessity of extracting traced from political purposes. ${ }^{16}$ Thus, states in regimes with democratic institutes are more willing to have a floating currency system so as to be able to implement an independent monetary policy for the stabilization of their internal status. ${ }^{17}$

Independency Degree of the Central Bank: studies show that replacing fixed currency rate and independency of central bank make it possible to adopt monetary policies for internal purposes. ${ }^{18}$ Transference of a currency system with more floating is related to an independent central bank. ${ }^{19}$ Finally, it can be claimed that the more independent a central bank, the more the probability of a floating currency system.

Development of a financial structure: structure of a financial system is also another crucial factor that determines the type of currency system. Developed financial system makes a floating currency system more

\footnotetext{
7 - Bjørnskov, C., (2005). "Political Ideology and Economic Freedom”. Working Paper 05-8. Department of Economics, Aarhus School of Business.

${ }^{8}$ - Bortolotti, B., Fantini, M., Siniscalco, D., (2003). "Privatization around the world: evidence from panel data". Journal of Public Economics 88, 305-332.

9 - Potrafke, N., (2010). "Does government ideology influence deregulation of product markets? Empirical evidence from OECD countries". Public Choice 143, 135-155.

10 - Benoit, K., Laver, M., (2006), Party Policy in Modern Democracies. Rout ledge, London.

11 - Hibbs, Ibid.

12 - Frieden, J., Leblang, D., Valev, N., (2010). "The political economy of exchange rate regimes in transition economies". The Review of International Organizations 5, 1-25.

13 - Broz, J.L., Frieden, J., (2001). “The political economy of international monetary relations". Annual Review of Political Science 4, 317343 .

14 - Mundell, R.A., (1963). "Capital mobility and stabilization policy under fixed and flexible exchange rates". The Canadian Journal of Economics and Political Science 29,475-485.

15 - Bernhard, W., Leblang, D., (1999). "Democratic institutions and exchange-rate commitments”. International Organization 53, 71-97.

16 - Broz, J.L., (2002). "Political system transparency and monetary commitment regimes". International Organization 56, 861-868.

17 - Leblang, D., (1999). "Political institutions and exchange rate commitments in the developing world". International Studies Quarterly 43, 599-620.

18 - Eijffinger, S., Hoeberichts, M., (2008). "The trade-off between central bank independence and conservatism in a New Keynesian framework". European Journal of Political Economy 24, 742-747.

${ }^{19}$ - Crowe, C., Meade, E., (2008). "Central bank independence and transparency: evolution and effectiveness". European Journal of Political Economy 24, 763-777.
} 
probable because developing a financial system reduces the importance of controlling the capital flow. ${ }^{20}$ Less developed counties are more probable to choose a fixed currency system because, A) They not have access to necessary marketing tools for optimal performance of the internal market ${ }^{21}$; and $\mathrm{B}$ ) they do this to support their inexperienced banking system against currency fluctuations. ${ }^{22}$ Therefore, high financially developed countries would choose the floating currency system with a greater possibility.

Economy size: another factor determining the currency system is economy size. Small-sized economies are willing to boost their share in international trade and, in so doing, they prefer a fixed currency system. ${ }^{23}$ In other terms, more developed countries are more probable to embrace a floating currency system. ${ }^{24}$ Furthermore, it is expected that capital flow be affected by interest rates and, in this way, affect the currency system. Hence, increase in internal interest rate might lead the country to adopting a fixed currency system due to rise in the state's financial expenses.

Inflation status: high inflation rate lead to decrease of economic competing power. ${ }^{25}$ So, economies with high inflation would often face fixed currency system in order to lower inflation and increase competing power in their tradable sectors. ${ }^{26}$

Oil rent: this variable in representative of the amount of dependency on oil. In this sense, the mentioned assumption in this study, i.e. varying oil income determining currency system is fixed, is considered important in the sense that oil income could have impeded many dynamics in economic structure of oil-production countries and so guide currency system to fixedness. What doubles the importance of this variable is that oil income and rent have influenced a large number of economic policy-making- or even non-economic- dimensions. Its importance in currency system is rooted in the notion that oil-rich countries are not too willing to optimize currency prices, and subsequently currency system, and often confront currency rate as nominal phenomenon. This variable indicates the difference between produced petroleum value at global level and its producing expenses, expressed as a function of net price (retrieved from Global Bank).

\section{Oil and Gas Price Fluctuations and Influential Factors}

One of the impediments on the way gaining benefit in contracts of oil and gas industry is price control by activists and the effective factors. Lack of balance in prices of this valuable commodity is very effective in benefits gained from oil contracts. As an example, the case of Iran and Turkey which was put forward by Turkey in International Court of Arbitration, claiming that gas imported from Iran is more expensive than that imported from other countries; also, for confirming its claim, Turkey has make reference to reduction of global oil prices and other fuels. This resulted in \% 10-15 reduction of Iranian gas prices imported to Turkey. Therefore, it can be seen that global oil and gas price fluctuations have direct influence on benefits of the involved countries. Moreover, previous research shows that great increase in oil price leads to fluctuation of global interest rate, while a small change in global interest rate can lead to significant fluctuations in oil prices. ${ }^{27}$ In addition, studies conducted on OPEC and oil prices, with a static model for OPEC as cartel and a marginalized group, propose that prices above the long-term price curve reduce share and influence of cartel in long-term, while they guide market towards instability in short-term. ${ }^{28}$ Although, through time, OPEC has great impact on fluctuation of pricing system, such influences are influential only after pricing shocks in the market; while cartel has

\footnotetext{
20 - Hossain, M., (2009). "Institutional development and the choice of exchange rate regime: a cross-country analysis". Journal of The Japanese and International Economies 23, 56-70.

${ }^{21}$ - Markiewicz, A., (2006). "Choice of exchange rate regime in transition economies: an empirical analysis". Journal of Comparative Economics 34, 484-498.

22 - Von Hagen, J., Zhou, J., (2007). "The choice of exchange rate regimes in developing countries: a multinomial panel analysis". Journal of International Money and Finance 26, 1071-1094.

23 - Markiewicz, A., (2006). "Choice of exchange rate regime in transition economies: an empirical analysis". Journal of Comparative Economics 34, 484-498.

24 - Poirson, H., (2001). "How Do Countries Choose Their Exchange Rate Regime?” IMF Working Paper WP/01/46.

25 - Bodea, C., (2010). "The political economy of fixed exchange rate regimes: the experience of post-communist countries". European Journal of Political Economy 26,248-264.

${ }^{26}$ - Frieden, J., Stein, E., (2001). “The Political Economy of Exchange Rate Policy in Latin America: An Analytical Overview”. In: Frieden, J., Stein, E. (Eds.), The Currency Game: Exchange Rate Politics in Latin America. Johns Hopkins University Press, Baltimore, pp. 1-20.

27 - Willman, E., Lowinger, T. and C. Wihlborg (1985), "OPEC in World Financial Markets: oil prices and interest rates", Journal of International Money and finance, Vol.4, pp.253-266.

28 - Green, D. L. (1991), “A note on OPEC market power and oil prices”, Energy Economic, Vol. 13. pp.123-129.
} 
adjusted to prices more than OPEC. ${ }^{29}$ Also, focusing on framework of markets in global pricing system, some believe that, since 2003, 'demand' lever was introduced as a significant factor for the global oil pricing system as a result of the emergence of China and Indian markets. ${ }^{30}$ Results differ for gas. These imply that in long term:

There is a significant negative relationship between global demand of gas and gas price;

There is a significant positive relationship between global demand of gas and time;

There is a positive relationship between marginalized group's supply and gas price;

There is a negative relationship between global gas price and demand balance of cartel;

There is a positive relationship between time and demand balance of cartel.

Also the obtained results show that with $1 \$$ increase in gas price, global demand decreases 0.95 trillion cube meters. Moreover, as a result of this $1 \$$ increase in the price, marginalized group's demand increases 3.05 trillion. On this basis, $1 \$$ increase in the price cause a 4 trillion cube meters decrease in gas price in GECF. ${ }^{31}$

\section{Inefficiencies in Management of Oil Income}

Developing countries with rich natural resources often confront with many challenges when attempting to transform these resources to other forms of energy which lead to sustainable development and guarantee economy against trade cycles occurred as a result of income imbalances. In general, fluctuation and finite lifetime of incomes obtained from unrecyclable resources would expose resource management of serious problems- these problems are the main impediments to benefit gain. Research has indicated that, in recent decades, fluctuations of oil global prices have been at least twice greater than those of other commodities. This is an indicative of the fact that trade arena is constantly influenced by oil global price and that income imbalances of an state would lead to negative effects on investments, income distribution and de-poverty plans and oil infrastructural projects in the country. On the other hand, evidence have indicated that shocks in oil prices are unpredictable and oil prices fluctuate a lot. These shocks might have their roots in diverse economic and political international factors and so they are Exogenous in relation to internal economy. ${ }^{32}$ In fact, distinguished characteristics of these countries such as low per capita income, rare internal investment and limited accessibility to global markets have led to impertinent tips suggested by consumption-saving-investment theories. So, attention was again shifted to development of infrastructures and extension of developmental plans in these countries through oil incomes. However, inability in management of public investment results in insufficient output in public and private investments in a large number of developing countries; this negligible output mostly takes place as a result of inappropriate selection and adoption of projects. ${ }^{33}$ All in all, these characteristics can have implications for economic function and economic stability of countries with natural resource.

\section{Conclusion}

According to what was mentioned above, other than having different types, investment contracts are of diverse dimensions, particularly in oil and gas industry, whose recognition can impose fundamental changes in benefitting structure of contracts; these dimensions can be political, economic, etc. So, in order to gain the most benefit from a contract, including investment contracts in oil and gas industry, type of the contracts, their commitment they end in and the reasons for which commitments are formed need to be recognized. Choice of the type of contract in its specific time is an important and influential factor in gaining benefit from a contract. However, different factors might affect benefit gain in oil and gas investment contracts.

So as to mitigate against the occurrence of these factors, each contract party needs to make use of its utmost negotiating power and the necessary skills for mitigating against them. In such situations, employing experienced negotiators is of vital importance since they can get the utmost benefit and impede giving illogical privileges.

\footnotetext{
29 - Bremond, V., Hashe, E. and V. Mignon (2012), "Does OPEC still exist as a cartel? An empirical investigation”, Energy Economic, Vol. 34. Pp. 125-131.

30 - Li, H., and S. Lin (2011), "Do Emerging Markets matter in the world oil pricing system? Evidence of imported crude by China and India”, Energy policy, No. 39, pp. 4624-4630.

31 - Golestani and other, 2013, Price Leadership and Collusion Models in Gas Cartel with use of Genetic Algorithm,(in persian) Journal of Energy and environment economic, Vol.2 no.6, P.151-182.

32 - Filis, G., Degiannakis, S. and CH. Floros (2011), "Dynamic Correlation between Stock Market and Oil Prices: the Case of Oillmporting and Oil-Exporting Countries", International Review of Financial Analysis, Vol. 20, Issue.3, pp.152-164.

33 - Dabla-Norris, Brumby, Kyobe, Annette, Mills, Zac and Chris Papageorgiou (2011), "Investing in Public Investment: An Index of Public Investment Efficiency”, IMF Working Paper, Strategy, Policy, and Review Department.
} 
It could be claimed that choice of a pertinent contract is more decisive than mere holding a negotiation with a powerful party. Choice of a pertinent contract is a very complex and technical job to accomplish, especially in diverse political, economic, military, certain geopolitical conditions of the country. This is not an easy job to be done by all persons and a specialized team of lawyers who are familiar with all dimensions, privileges and commitments a contract might offer and who can recognize the contract setting and perform the required analysis in legal terms.

Selection of an appropriate contract is more beneficiary than appropriate political and social conditions, a good party or any other factor. In other words, when economic policy-making in the host country precedes an open and stable economic atmosphere, risks of making contracts and investment would decrease and more foreign investment would be welcomed. Existence of an appropriate and disciplined economic structure is one of the most important factors either in attracting foreign investment or entering into oil contracts. Thus, making attempts to reform outdated and inefficient economic structures is a prerequisite to gaining benefit in oil contracts.

All in all, the more democratic the political structure, the more probable it is to adopt a floating currency system. Further, states with a tendency toward the left-party tend to a floating currency system and then probability of adopting a fixed currency system is reduced to the same extent. Oil rent is another effective factor on choice of currency system; for countries with more oil rents with more dependency on oil incomes, fixed currency system could be a more desirable choice. Economy size is another explanatory variable in the sense that the larger the economy size the more probable selection of a floating currency system and the less probable a fixed currency system.

What is noteworthy here is that, according to the literature, both economic and political structure in states with oil rents are in some way influenced by rent incomes. Because of this, it can be claimed that the main variable in explaining the present research problem is, in fact, amount and size of rent incomes and the amount of dependency on them. In this respect, rent incomes can have impacts on variables of the state's 'economy size', 'political structure' and 'political attitude'.

As mentioned above, oil and gas price fluctuations within the global market have significant effects on parties' benefits in an oil contract. Therefore, before entering into a contract, it is necessary to foresee a proper technical and legal metabolism so as to keep away from possible crises. Management of oil incomes, particularly sustainably, is one of the most important factors of gaining benefits in oil contracts. These can be emerged from many different factors. Hence, devising a framework of pertinent financial and monetary policies, along with a precise planning for creating economic stability, can significantly help enhance the betterment and efficiency of oil resource management. This requires fair knowledge of the effects of oil income impulses on macro-economic, real and nominal, variables.

\section{References}

Benoit, K., \& Laver, M. (2006). Party Policy in Modern Democracies. Rout ledge, London.

Bernhard, W., \& Leblang, D. (1999). Democratic institutions and exchange-rate commitments. International Organization, 53, 71-97. http://dx.doi.org/10.1162/002081899550814

Bjørnskov, C. (2005). Political Ideology and Economic Freedom. Working Paper 05-8. Department of Economics, Aarhus School of Business.

Bodea, C. (2010). The political economy of fixed exchange rate regimes: the experience of post-communist countries. European Journal of Political Economy, 26, 248-264. http://dx.doi.org/10.1016/j.ejpoleco.2009.12.005

Bortolotti, B., Fantini, M., \& Siniscalco, D. (2003). Privatization around the world: evidence from panel data. Journal of Public Economics, 88, 305-332. http://dx.doi.org/10.1016/S0047-2727(02)00161-5

Bremond, V., Hashe, E., \& Mignon, V. (2012). Does OPEC still exist as a cartel? An empirical investigation. Energy Economic, 34, 125-131. http://dx.doi.org/10.1016/j.eneco.2011.03.010

Broz, J. L. (2002). Political system transparency and monetary commitment regimes. International Organization, 56, 861-868. http://dx.doi.org/10.1162/002081802760403801

Broz, J. L., \& Frieden, J. (2001). The political economy of international monetary relations. Annual Review of Political Science, 4, 317-343. http://dx.doi.org/10.1146/annurev.polisci.4.1.317

Crowe, C., \& Meade, E. (2008). Central bank independence and transparency: evolution and effectiveness. European Journal of Political Economy, 24, 763-777. http://dx.doi.org/10.1016/j.ejpoleco.2008.06.004 
Dabla-Norris, B., Kyobe, A., Mills, Z., \& Papageorgiou, C. (2011). Investing in Public Investment: An Index of Public Investment Efficiency. IMF Working Paper, Strategy, Policy, and Review Department.

Eijffinger, S., \& Hoeberichts, M. (2008). The trade-off between central bank independence and conservatism in a New Keynesian framework. European Journal of Political Economy, 24, 742-747. http://dx.doi.org/10.1016/j.ejpoleco.2008.06.001

Filis, G., Degiannakis, S., \& Floros, C. H. (2011). Dynamic Correlation between Stock Market and Oil Prices: the Case of OilImporting and Oil-Exporting Countries. International Review of Financial Analysis, 20(3), 152-164. http://dx.doi.org/10.1016/j.irfa.2011.02.014

Frieden, J., \& Stein, E. (2001). The Political Economy of Exchange Rate Policy in Latin America: An Analytical Overview. In Frieden, J., \& Stein, E. (Eds.), The Currency Game: Exchange Rate Politics in Latin America (pp. 1-20). Johns Hopkins University Press, Baltimore.

Frieden, J., Leblang, D., \& Valev, N., (2010). The political economy of exchange rate regimes in transition economies. The Review of International Organizations, 5, 1-25. http://dx.doi.org/10.1007/s11558-009-9072-7

Golestani and other. (2013). Price Leadership and Collusion Models in Gas Cartel with use of Genetic Algorithm,(in persian). Journal of Energy and environment economic, 2(6), 151-182.

Green, D. L. (1991). A note on OPEC market power and oil prices. Energy Economic, 13, 123-129. http://dx.doi.org/10.1016/0140-9883(91)90044-Z

Hibbs, D. (1977). Political parties and macroeconomic policies. The American Political Science Review, 71, 1467-1487. http://dx.doi.org/10.2307/1961490

Hossain, M. (2009). Institutional development and the choice of exchange rate regime: a cross-country analysis. Journal of The Japanese and International Economies, 23, 56-70. http://dx.doi.org/10.1016/j.jjie.2008.12.001

Leblang, D. (1999). Political institutions and exchange rate commitments in the developing world. International Studies Quarterly, 43, 599-620. http://dx.doi.org/10.1111/0020-8833.00138

Li, H., \& Lin, S. (2011). Do Emerging Markets matter in the world oil pricing system? Evidence of imported crude by China and India. Energy policy, (39), 4624-4630. http://dx.doi.org/10.1016/j.enpol.2011.05.003

Markiewicz, A. (2006). Choice of exchange rate regime in transition economies: an empirical analysis. Journal of Comparative Economics, 34, 484-498. http://dx.doi.org/10.1016/j.jce.2006.06.004

McKinnon, R. (1963). Optimum currency areas. American Economic Review, 53, 717-725.

Mohamed Daly Sfia. (2010). The choice of exchange rate regimes in the MENA countries: a probit analysis. Int Econ Econ Policy, 8, 275-305. http://dx.doi.org/10.1007/s10368-010-0169-5

Mundell, R. A. (1963). Capital mobility and stabilization policy under fixed and flexible exchange rates. The Canadian Journal of Economics and Political Science, 29, 475-485. http://dx.doi.org/10.2307/139336

Mundell, R. A.(1969). Toward a Better International Monetary System. Journal of Money Credit and Banking, 3, 625-648. http://dx.doi.org/10.2307/1991217

Poirson, H. (2001). How Do Countries Choose Their Exchange Rate Regime? IMF Working Paper WP/01/46.

Potrafke, N. (2010). Does government ideology influence deregulation of product markets? Empirical evidence from OECD countries. Public Choice, 143, 135-155. http://dx.doi.org/10.1007/s11127-009-9494-z

Shiravi, A. (2014). oil and gas law(in persian). Tehran: Mizan.

Von Hagen, J., \& Zhou, J. (2007). The choice of exchange rate regimes in developing countries: a multinomial panel analysis. Journal of International Money and Finance, 26, 1071-1094. http://dx.doi.org/10.1016/j.jimonfin.2007.05.006

Willman, E., Lowinger, T., \& Wihlborg, C. (1985). OPEC in World Financial Markets: oil price s and interest rates. Journal of International Money and finance, 4, 253-266. http://dx.doi.org/10.1016/0261-5606(85)90047-6

\section{Copyrights}

Copyright for this article is retained by the author(s), with first publication rights granted to the journal.

This is an open-access article distributed under the terms and conditions of the Creative Commons Attribution license (http://creativecommons.org/licenses/by/3.0/). 